\title{
Adsorption of Biomolecules and Polymers on Silicates, Glasses, and Oxides: Mechanisms, Predictions, and Opportunities by Molecular Simulation
}

\author{
by \\ Hendrik Heinz \\ Department of Chemical and Biological Engineering, University of Colorado-Boulder, Boulder, \\ CO 80309, USA \\ * Corresponding author: hendrik.heinz@ colorado.edu
}

1 of 21

(C) 2016. This manuscript version is made available under the Elsevier user license

http://www.elsevier.com/open-access/userlicense/1.0/ 


\begin{abstract}
Silicates, glasses, and oxides are widely used in everyday applications such as surfaces of cell phones and tablets as well as in nanostructured form for therapeutics, catalysts, and composites. Modeling of the inorganic-organic interfaces at the 1 to $100 \mathrm{~nm}$ scale has recently become more viable as suitable force fields and molecular models including details of oxide surface chemistry and $\mathrm{pH}$ dependent ionization have been introduced. Here we describe computational models for glasses, silica, and common oxides for simulations at high temperatures and at room temperature, including necessary chemical specificity to analyze surfaces and organic interfaces. The bulk structure of glasses, surface chemistry and type of molecular interactions governing adsorption, as well as the feasible accuracy is illustrated by examples. Applications and opportunities of simulation methods are discussed.
\end{abstract}

Keywords: minerals; oxides; glasses; biomolecules; adsorption; molecular simulation; organic-inorganic interfaces 


\section{Introduction}

Oxides, silicates and glasses have been studied for centuries and are widely used in everyday applications such as glass surfaces for windows and displays, surfaces of cell phones and tablets as well as in nanostructured form for therapeutics, catalysts, and composites. ${ }^{1-5}$ The interaction with conventional polymers, biomacromolecules such as peptides and DNA, is critical to design mechanically resistant coatings, tags for molecular recognition, and systems for drug delivery. Therefore, recent applications include nanostructures for polymer composites, drug delivery vehicle, catalyst supports, sensors, and other functional materials. ${ }^{6-20}$ Measurements of surface areas with the Brunauer-Emmett-Teller (BET) method, thermal gravimetric analysis (TGA), surface adsorption of gases and liquids, spectroscopy, as well as of ionization of silanol surface groups have been carried out by numerous research teams. ${ }^{21-38}$ Glasses are typically produced from oxide melts of various composition, often the Stober method based on hydrolysis of liquid precursors is applied to synthesize nanostructured and microstructured silica. ${ }^{23}$ Recent studies also explored the use of biomimetic synthesis approaches of various oxides using soluble precursors in combination with amines and peptide-based ligands. ${ }^{7,12,39-44}$ Such nucleation and growth approaches enable control over average particle size, as well as over the surface chemistry and surface acidity (Figure 1). ${ }^{9,45-48}$ Experimental data show that silica surfaces, as a representative example, exhibit wide variation in the area density of silanol groups depending on synthesis and thermal processing. Most glasses display about $4.7 \mathrm{SiOH}$ groups per $\mathrm{nm}^{2}{ }^{33}$ Of these silanol groups, a major fraction ionizes to siloxide groups (e.g. $\mathrm{SiO}^{-} \cdots \mathrm{Na}^{+}$) at $\mathrm{pH}$ values above $\sim 3$, depending on surface chemistry, $\mathrm{pH}$, and ionic strength (Figure 1) ${ }^{49}$ Further insight into bulk and surface properties has also been obtained from imaging techniques such as transmission electron microscopy (TEM) and scanning electron microscopy (SEM), X-ray and 
neutron diffraction, Infrared (IR) and nuclear magnetic resonance (NMR) spectroscopy, X-ray photoelectron spectroscopy (XPS), as well as by extended x-ray absorption fine structure (EXAFS) measurements which yield elemental coordination numbers.

a
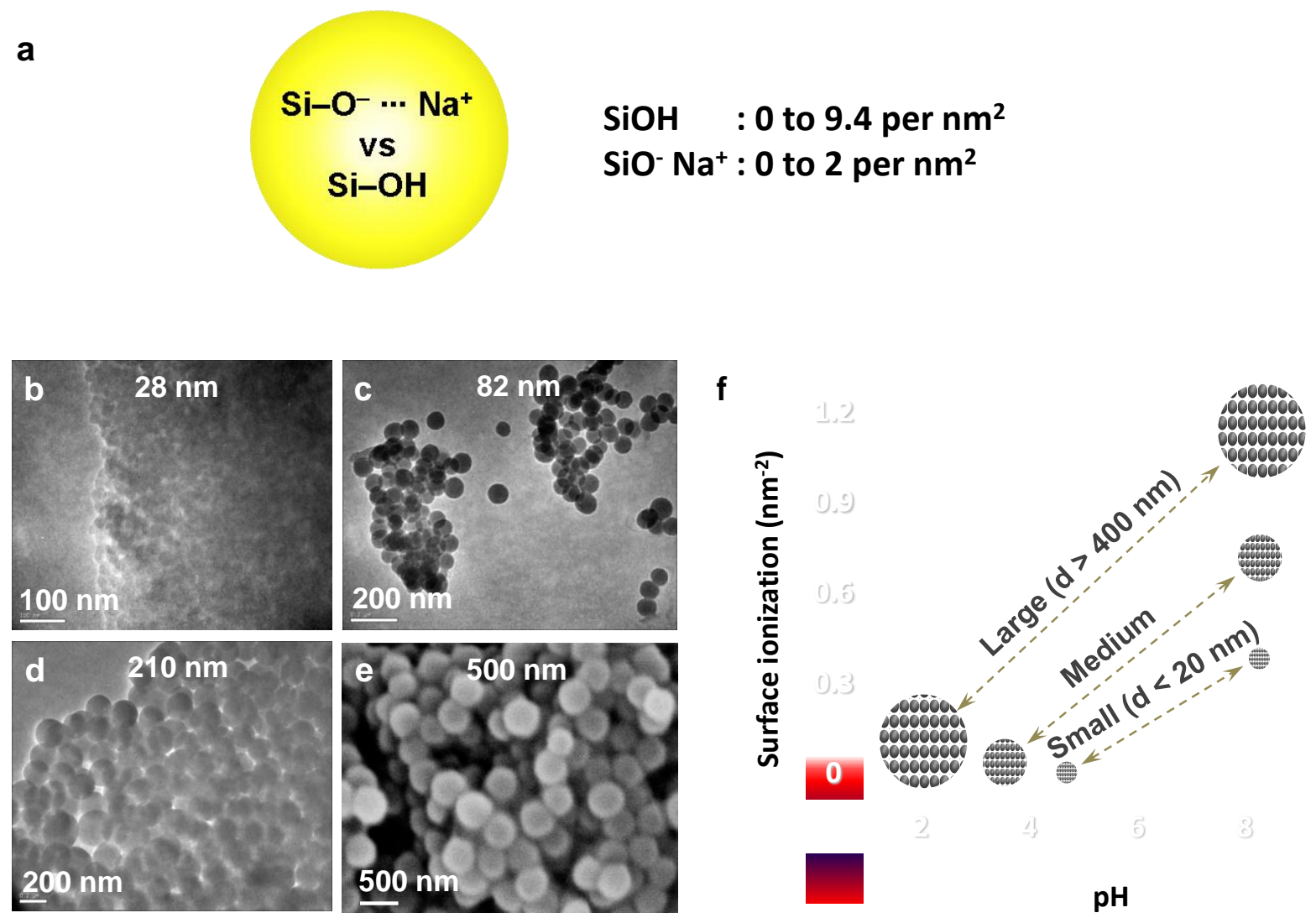

Figure 1. Surface structure of silica glasses and nanoparticles. (a) Range of the area density of silanol groups and metal siloxide groups per square nanometer (shown for sodium siloxide). (b-e) TEM and SEM images of amorphous silica nanoparticles of different size from Stöber-type synthesis. Silica nanoparticles of size $28 \mathrm{~nm}$ are less dense and poorly defined in comparison to spherical larger particles of 82, 210, and $500 \mathrm{~nm}$ size (from ref. ${ }^{48}$ ). (f) Effect of $\mathrm{pH}$ and particle size on surface ionization (from refs. ${ }^{48,49}$ ). Large nanoparticles contain $\mathrm{Q}^{2} / \mathrm{Q}^{3}$ surface environments $\left(=\mathrm{Si}(\mathrm{OH} / \mathrm{ONa})_{2}=\mathrm{Si}(\mathrm{OH} / \mathrm{ONa})\right.$ groups $)$, medium sized and smaller nanoparticles 
contain mostly $\mathrm{Q}^{3}$ environments $\left(\equiv \mathrm{Si}(\mathrm{OH} / \mathrm{ONa})\right.$ groups). The total amount of $\mathrm{SiO}^{-} \mathrm{Na}^{+}$groups per $\mathrm{nm}^{2}$ is shown at an ionic strength of $0.1-0.3 \mathrm{~mol} \cdot \mathrm{dm}^{-3}$ (see original data in refs. ${ }^{9,21,24,30,38}$ ).

\section{Molecular Models for Silicates and Glasses}

Computer simulation studies of silica and glasses emerged in the 1980's, starting with work by Garofalini et al and Catlow et al. ${ }^{50-61}$ The focus of the first models was primarily on understanding bulk properties of silica and glasses. Since then, simulations of bulk silica and glasses have been reported with several newer potentials. ${ }^{11,49,62-78}$ Among them, the widely used BKS potential is a nonbonded potential suitable for the simulation of bulk and mechanical properties up to several $1000 \mathrm{~K} .{ }^{54}$ The Pedone potential is an extension of this potential and suitable for silica glasses of variable composition that contain sodium and aluminum besides silicon dioxide (Figure 2). ${ }^{71,79}$ The INTERFACE potential is a bonded potential that reproduces surface properties and allows the simulation of interfaces with water, biomolecules, and polymers (Figure 3 ). ${ }^{49,80}$

From a fundamental perspective, the interatomic potentials ought to mimic chemical bonding, dipolar interactions, and van-der-Waals interactions that determine cohesion, surface forces, and interfacial forces. Thereby, the balance of covalent versus ionic bonding is essential and described by atomic charges within the framework of interatomic potentials. ${ }^{62}$ Multiple evidence has shown that the $\mathrm{Si}$ charge in tetrahedral oxygen coordination is $+1.1 \mathrm{e}( \pm 0.1 \mathrm{e})$, i.e., the $\mathrm{Si}-\mathrm{O}$ bond is about $70 \%$ covalent and $30 \%$ ionic. Nevertheless, widely scattered atomic charges in the range of $+0.5 \mathrm{e}$ to $+4 \mathrm{e}$ for $\mathrm{Si}$ in tetrahedral oxygen coordination are still common in current force fields. ${ }^{11,54,55,69,71,75,81-83}$ Significantly deviant atomic charges lead up to $500 \%$ deviations in computed interfacial properties and compromise structural stability in the models as 

contributions to bonding are neglected and compensated for by higher charges, such as $+2.4 \mathrm{e}$ for $\mathrm{Si}$, to maintain cohesion and avoid structural collapse. Appropriately matched Lennard-Jones or other compensating repulsive energy terms offset the excess Coulomb cohesion. The advantage of the nonbonded potentials is that bulk properties such as structures and mechanical properties can be well reproduced, and dynamic reassignment of bonds, especially at high temperatures, can be conveniently followed in molecular simulations as terms for covalent bonding are not included and thus do not require reassignments.

When surface and interfacial properties become of interest, however, chemically realistic bonded potentials such as in the INTERFACE force field need to be employed. ${ }^{49,78}$ The INTERFACE force field, including the INTERFACE-CHARMM and INTERFACE-PCFF implementations, includes the full range of surface chemistry of silica, $\mathrm{pH}$ dependent changes in silanol ionization, and full mobility of all atoms. The appropriate area density of SiOH groups and $\mathrm{SiO}^{-} \ldots \mathrm{Na}^{+}$can be implemented in models according to the surface chemistry and $\mathrm{pH}$ known from experiment. Binding of peptides and polymers can be studied in aqueous solution at the 1 to $100 \mathrm{~nm}$ scale including details of $\mathrm{pH}$, ionic concentrations, surface coverage, and sequence of biopolymers in correspondence with experimental data (Figure 3). A limitation of the bonded potentials such as INTERFACE is the difficulty to break bonds so that simulations of phase transitions in silicate melts at high temperatures is not easily possible. ${ }^{49}$

The study of both bulk and surface properties can thus benefit from a synergistic combination of nonbonded-only potentials and fully bonded potentials. The nonbonded-only potentials can generate morphologies for various temperatures and compositions that can serve as an input for chemically accurate bonded potential with realistic atomic charges and atom types 
to evaluate atomic positions and surface properties. The BKS, Pedone, and INTERFACE potential also use comparatively few parameters, allowing understanding of every parameter through a chemical rationale and enable modifications.

Alternatives to simulate bond breaking are Morse potentials and specific reactive potentials like ReaxFF. ${ }^{84,85}$ Morse potentials are a straightforward alternative to simulate bond breaking with few parameters and can be combined with established harmonic potentials for organic compounds. ${ }^{85}$ Reactive potentials such as ReaxFF involve parameterizations with numerous empirical terms and adjustable parameters, posing more challenges to interpret results and improve the potential if necessary. ${ }^{84}$
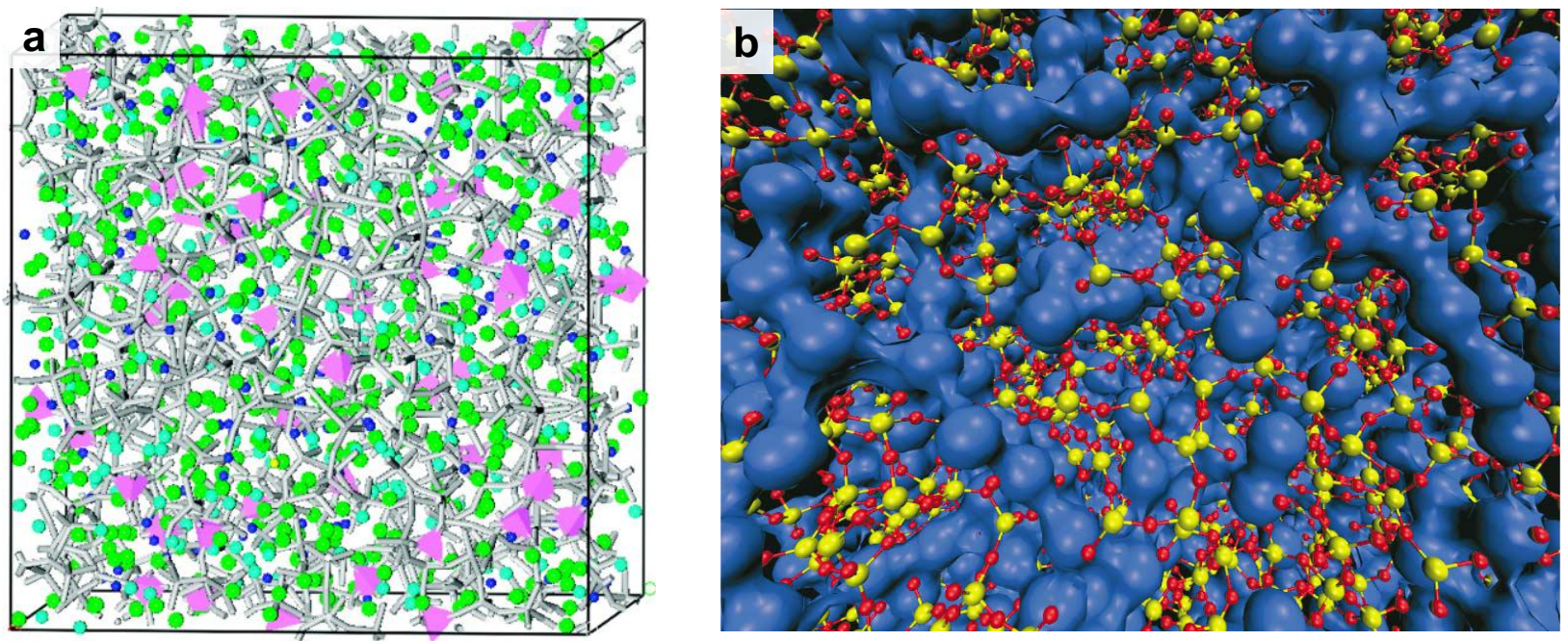

Figure 2. Structure of bulk glasses from molecular simulation. (a) Snapshot of a bioactive glass of the composition $46.2 \mathrm{SiO}_{2} \cdot 24.3 \mathrm{Na}_{2} \mathrm{O} \cdot 16.9 \mathrm{CaO} \cdot 2.6 \mathrm{P}_{2} \mathrm{O}_{5} \cdot 10 \mathrm{CaF}_{2}$. Gray sticks represent the $\mathrm{Si}-\mathrm{O}$ framework, green spheres represent $\mathrm{Na}$, cyan spheres represent $\mathrm{Ca}$, blue spheres represent $\mathrm{F}$, and violet tetrahedra represent the $\mathrm{PO}_{4}$ units (reproduced with permission from ref. $\left.{ }^{79}\right)$. (b) Snapshot of the structure of sodium trisilicate $\left(3 \mathrm{SiO}_{2} \cdot 1 \mathrm{Na}_{2} \mathrm{O}\right)$ at $2100 \mathrm{~K}$ at a density of $2.2 \mathrm{~g} / \mathrm{cm}^{3}$. The Si-O network is drawn by yellow $(\mathrm{Si})$ and red $(\mathrm{O})$ spheres that are connected to 7 of 21 
each other by covalent bonds shown as sticks between Si and O spheres. The blue spheres that are in the vicinity of each other represent the $\mathrm{Na}$ atoms, which align in channels that percolate trough the Si-O structure (reproduced with permission from ref. ${ }^{86}$ ).
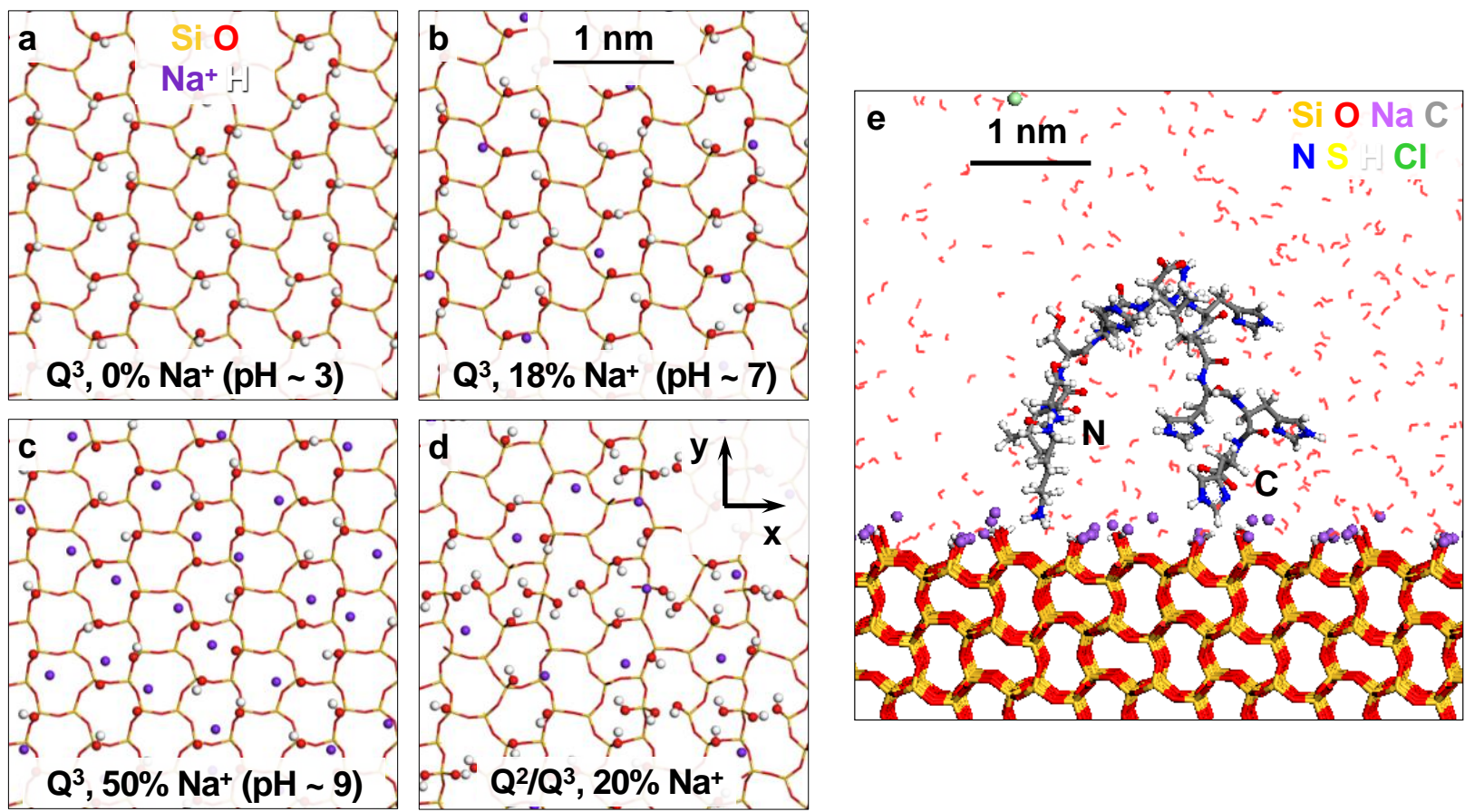

Figure 3. Surface models of silica glasses in top view (a-d) and the structure of aqueous biological interfaces from molecular simulation (e). The model surfaces represent different common surface chemistries and $\mathrm{pH}$ values. (a-c) Regular $\mathrm{Q}^{3}$ silica surfaces with $4.7 \mathrm{SiO}(\mathrm{H}, \mathrm{Na})$ groups per $\mathrm{nm}^{2}$ and different amount of $\mathrm{SiO}^{-} \mathrm{Na}^{+}$groups represent surfaces of typical glasses and silica nanoparticles ( $<200 \mathrm{~nm}$ size) at $\mathrm{pH}$ values of $\sim 3, \sim 7$, and $\sim 9$. (d) A regular $\mathrm{Q}^{2} / \mathrm{Q}^{3}$ silica surface with $6.5 \mathrm{SiO}(\mathrm{H}, \mathrm{Na})$ groups per $\mathrm{nm}^{2}$ and $20 \%$ ionization represents somewhat larger silica nanoparticles (> $200 \mathrm{~nm}$ ) at $\mathrm{pH}$ 7. A higher area density of both $\mathrm{SiOH}$ and of $\mathrm{SiO}^{-} \mathrm{Na}^{+}$ groups then results in stronger adsorption of peptides (reproduced with permission from ref. ${ }^{78}$ ). (e) Snapshot of a silica-binding peptide $\left(\mathrm{K}(+)\right.$ SLSRHDHIHHH(-)) adsorbed on a regular $\mathrm{Q}^{3}$ silica surface in aqueous solution in all-atomic detail at $\mathrm{pH} \sim 9$ in side view. The location of $\mathrm{N}$ 8 of 21 
and $\mathrm{C}$ termini is highlighted. The peptide is mainly bound to the surface by Lys, Arg, Ser, and sometimes His residues. Larger and smaller grooves on the $\mathrm{Q}^{3}$ silica surfaces are notable (reproduced with permission from ref. ${ }^{9}$ ).

\section{Bulk Properties of Glasses}

Nonbonded potentials like BKS and Pedone made significant contributions to understanding structure and dynamics of glasses (Figures 2). The structure of a complex silica glass containing sodium, calcium, and phosphate is shown in Figure 2a. ${ }^{79}$ The distribution of ions in this material appears generally random. The composition including some $\mathrm{Ca}$ and $\mathrm{P}$ oxide was shown to support the formation of collagen and hydroxyapatite when implanted in the human body, and therefore the term "bioactive" glass was coined. Structural details obtained from the nonbonded potential somewhat depart from real data obtained by spectroscopy ( $\mathrm{Si}-\mathrm{O}$ bonds were artificially added for visualization purposes). Simulations of the structure of a sodium trisilicate melt at $2100 \mathrm{~K}$ revealed the formation of sodium channels in the amorphous structure (Figure $2 \mathrm{~b}) .{ }^{86}$ The sodium trisilicate stoichiometry of $3 \mathrm{SiO}_{2} \cdot 1 \mathrm{Na}_{2} \mathrm{O}$ leads to a disrupted framework of covalent bonds in silica with ionic contributions from sodium. The presence of sodium oxide within silica essentially breaks down the covalent network of silica $\left(\mathrm{SiO}_{2}\right)$ with coordination numbers of 4 and 2 into fragmented cross-linked rings. Thereby, every unit of $\mathrm{Na}_{2} \mathrm{O}$ leads to the dissociation of a $\equiv \mathrm{Si}-\mathrm{O}-\mathrm{Si} \equiv$ bond into two sodium siloxide fragments $\equiv \mathrm{Si}^{-} \mathrm{O}^{-} \cdots \mathrm{Na}^{+} / \mathrm{Na}^{+} \cdots{ }^{-} \mathrm{O}-\mathrm{Si} \equiv$. The remaining sodium ions then organize into locally regular coordination patterns around the siloxide groups and give the appearance of channels. Further information from simulation of bulk glasses also includes pair distribution functions and structure factors that can be compared to experimental measurements. ${ }^{79,86,87}$

9 of 21 


\section{Surface Properties and Selective Adsorption of Biopolymers on Glasses and Oxides}

Surface properties of glasses and silica depend on the surface chemistry and solution conditions such as $\mathrm{pH}$ (Figure 1). ${ }^{21-38}$ The predominantly covalent nature of bonding is then essential to conceive realistic models, and suitable models for silica take into account the area density of silanol groups and of siloxide groups, as well as potential surface porosity (Figure 3). The design of customized surface models as a function of particle origin, thermal processing, and $\mathrm{pH}$ is described in detail in ref. ${ }^{49}$. The selective adsorption of biomolecules, drugs, and polymers strongly depends on such conditions and can be quantitatively predicted with justified assumptions of the surface chemistry and solution conditions. ${ }^{78}$ The sequence similarity of attracted peptides to the same glass surface at different $\mathrm{pH}$, or for different silica particle size is often rather low $(<20 \%)$, which illustrates the high impact of different surface chemistry. ${ }^{9,78}$ The amino acid sequence has a similar impact on adsorption given the same surface chemistry and $\mathrm{pH}$, and specific binding energies as well as adsorbed conformations have been explained using molecular simulations. The mechanism of adsorption includes ion pairing, hydrogen bonds, conformation effects, as well as hydrophobic interactions. ${ }^{9},{ }^{78}$ The underlying reason for major differences in adhesion observed in experiment, when $\mathrm{pH}$ values or surface chemistry change, are shifts in the mechanism of adsorption among the categories of ion pairing, hydrogen bonds, conformation effects, and hydrophobic interactions. At high surface ionization (high $\mathrm{pH}$ ), ion pairing is dominant and adsorption mainly occurs through cationic groups such as ammonium groups at the $\mathrm{N}$ terminus or in lysine residues, as well as through guanidinium residues in arginine (Figure 3e). The rest of the peptide is often not in direct contact with the surface as the hydration shells of ions on the ionic surfaces keep other residues away. At lower degree of 

ionization, hydrogen bonding and hydrophobic interactions gain importance, and several functional groups can be found in proximity to the surface. Near the point of zero charge, when the surface is fully terminated by silanol groups, hydrophobic interactions are dominant; then the residues are adsorbed to the surface to avoid disruptions of the network of hydrogen bonds in the aqueous phase. ${ }^{47,78}$ Conformation effects are also critical, especially for longer peptides and for proteins. The stiffness of the backbone and specific residue-surface interactions have an impact on the binding energies.

Similar concepts also apply to other oxide surfaces. Thermodynamically consistent force field parameters and a chemically realistic implementation of the surface chemistry are necessary for accurate model predictions. The force field parameters need to include chemically justified atomic charges, reproduce the crystal structure of a model solid including flexibility of all atoms, and at least one surface property such as cleavage energy, hydration energy, or surface tension in agreement with experiment. Usually, with validation of one surface property, as it relates to the energy of the classical Hamiltonian, other surface and interfacial properties will be about equally reliable, and secondary validation often shows that thermal and mechanical properties (i.e. the first and second derivatives of the energy) are also in good agreement with experiment. ${ }^{80}$ The second major condition for meaningful predictions of adsorption is the implementation of key aspects of surface chemistry (Figure 4). For example, carbonates are often found as a biomineral, tricalcium silicate is the major component in Portland cement, hydroxyapatite occurs in bone and teeth, and titania surfaces are used in optical materials. Major aspects of surface properties are determined by the relevant $\mathrm{pK}$ values of the present acids and bases (Figure 4). Even though experimental data and fundamental chemical knowledge have been available for decades, the inclusion of realistic surface chemistry as a function of $\mathrm{pH}$ in computational models is 11 of 21 
surprisingly recent. ${ }^{80}$ Calcium carbonate has been the subject of numerous experimental and theoretical studies on biomineral formation and simple acid-base theory indicates hydrogen carbonate termination above $\mathrm{pH}$ values of 6 , related to the $\mathrm{pK}$ values of carbonic acid $\left(\mathrm{H}_{2} \mathrm{CO}_{3}\right.$, $\mathrm{p} K_{\mathrm{a} 1}=3.6$ for $\mathrm{H}_{2} \mathrm{CO}_{3}$ only/6.3 including $\left.\mathrm{CO}_{2}(\mathrm{aq}), \mathrm{pK}_{\mathrm{a} 2}=10.32\right)$ (Figure $\left.4 \mathrm{a}\right) .{ }^{88}$ Computational and even many experimental studies to-date still assume the exclusive presence of $\mathrm{CO}_{3}{ }^{2-}$ surface termination, ${ }^{19,89-91}$ which is a severe (and likely unintended) neglect of the impact by $\mathrm{HCO}_{3}{ }^{-}$ termination on nucleation, ligand recognition, and crystal growth of various calcium carbonate phases. Significant work remains to be undertaken to truly understand and control the underlying mechanisms. Models for silica and silicate surfaces were recently introduced and correlate with changes in protonation state near the $\mathrm{pK}$ values of the underlying acids such as silicic acid $\left(\mathrm{H}_{4} \mathrm{SiO}_{4}, \mathrm{pK}_{\mathrm{a} 1}=9.84, \mathrm{pK}_{\mathrm{a} 2}=13.2\right.$ at $\left.25^{\circ} \mathrm{C}\right)$ (Figure $\left.4 \mathrm{~b}\right) .{ }^{9,} 49,77,88$ Apatite surface models as a function of $\mathrm{pH}$ are also very recent (Figure 4c). ${ }^{92,93}$ The underlying $\mathrm{pK}$ values for phosphoric acid dictate the kind of phosphate species and $\mathrm{Ca}^{2+}$ area density found in the surface layers, further supported by spectroscopic data on $\mathrm{H}_{2} \mathrm{PO}_{4}{ }^{-} / \mathrm{HPO}_{4}^{-}$termination $\left(\mathrm{H}_{3} \mathrm{PO}_{4}, \mathrm{pK}_{\mathrm{a} 1}=2.15\right.$, $\mathrm{pK}_{\mathrm{a} 2}=7.20, \mathrm{pK}_{\mathrm{a} 3}=12.32$ at $\left.25^{\circ} \mathrm{C}\right) .{ }^{94,} 95$ Several prior simulation studies of hydroxyapatite interfaces with water and biomolecules assumed phosphate termination that corresponds to $\mathrm{pH}$ $>15 .^{96-102}$ These conditions correspond to immediate cell death. Physiological $\mathrm{pH}$ values of 5 to 6 such as found in bone are more appropriate and remain to be studied in detail. Surface protonation of titania is governed by a point of zero charge near $\mathrm{pH} 5.5$ (Figure 4d). ${ }^{103}$

The examples show that experimental data for protonation/deprotonation equilibria of oxide surfaces are well known for many minerals and can be implemented in models for simulations. Even if not available, chemical analogies to similar compounds can provide guidance. The inclusion of details of surface chemistry is essential for predictive simulations of binding of 12 of 21 
polymers, drugs, and guidance in nanomaterial design by simulation (Figure 5). It has been shown that binding constants of polymers and drugs vary over many orders of magnitude upon changes in surface chemistry and are semi-quantitatively predictable by molecular simulation using realistic models. ${ }^{78,93}$ Examples of ligand binding have also been reported on metal nanostructures, including mechanisms of facet recognition, crystal growth, shape control, and reactivity in catalysis. ${ }^{104-111}$ Simulations can significantly advance the understanding of experimental observations and guide in materials testing, as it remains challenging to monitor surface species directly by imaging techniques. Unprecedented understanding of oxide interfaces in predictive molecular specificity and atomic resolution at the 1 to $100 \mathrm{~nm}$ scale is becoming accessible using more predictive force fields and surface models. 
a

Solution interface

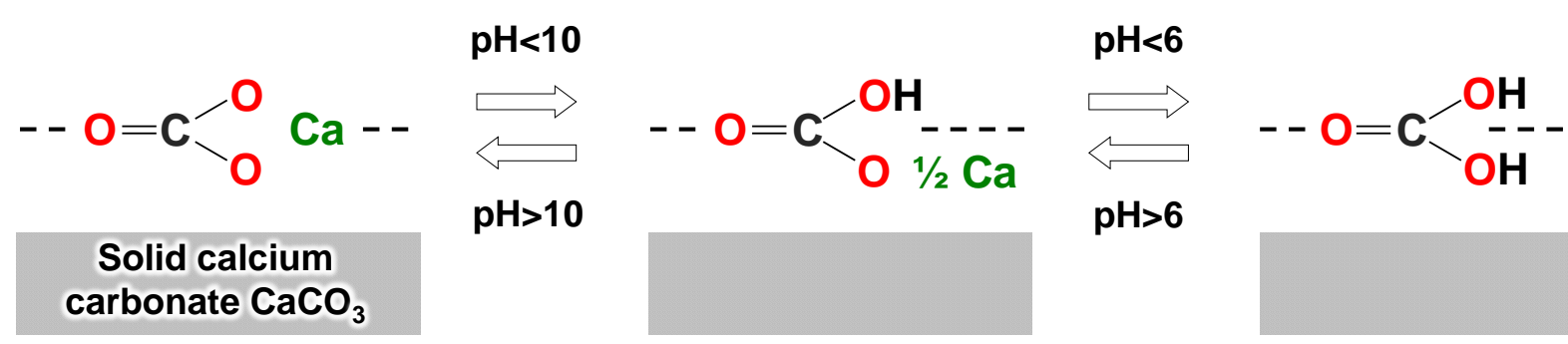

b

Solution interface<smiles>O[Si](O)(O)(O)(O)Cl</smiles>

$\mathrm{pH}<15$

Solid tricalcium

$\mathrm{pH}>15$<smiles>[O-][Si]([O-])([O-])([O-])([O-])O</smiles>

$\mathrm{pH}<12$<smiles>C[Si](C)(O)(O)(O)O</smiles>
silicate $\mathrm{Ca}_{3} \mathrm{SiO}_{5}$

C

Solution interface<smiles>CP(=O)([O-])O[Na]</smiles>

$\mathrm{pH}<12.5$<smiles>CP(=O)(O)O</smiles>

$\mathrm{pH}<7.5$

pH>12
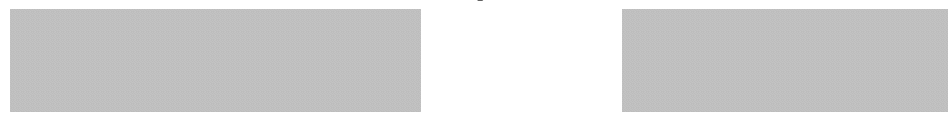

\section{Solid hydroxyapatite}

$\mathrm{Ca}_{10}\left(\mathrm{PO}_{4}\right)_{6}(\mathrm{OH})_{2}$

$\mathrm{pH}>12.5$

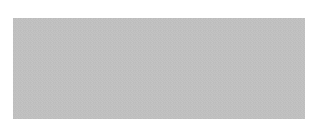

$\mathrm{pH}>7.5$<smiles>CP(=O)([O-])O</smiles>

d

Solution interface

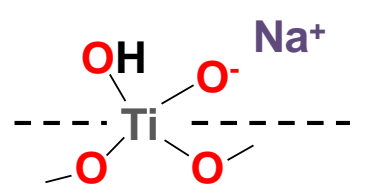

$\mathrm{pH}<7$

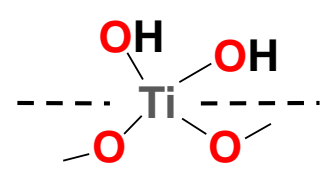

$\mathrm{pH}>7$

$\mathrm{pH}<3$

Cl-

Solid titania $\mathrm{TiO}_{2}$

$\mathrm{pH}>3$
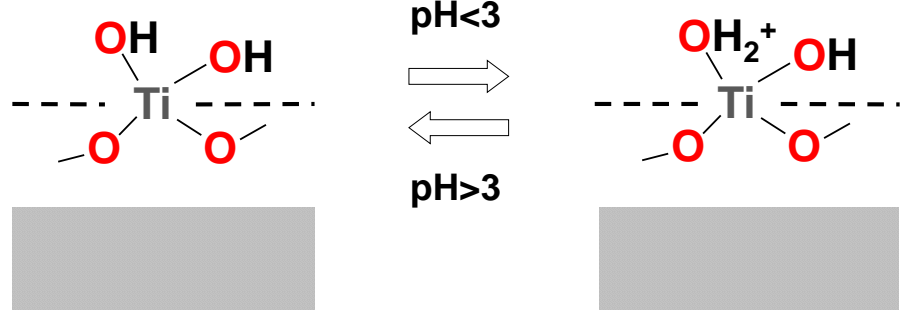
Figure 4. Common oxide surfaces and the $\mathrm{pH}$ dependent surface chemistry. (a) Calcium carbonate. (b) Calcium trisilicate and initial hydration. (c) Hydroxyapatite. (d) Titania. The changes in protonation state are related to $\mathrm{pK}$ values of the underlying acids (see text).
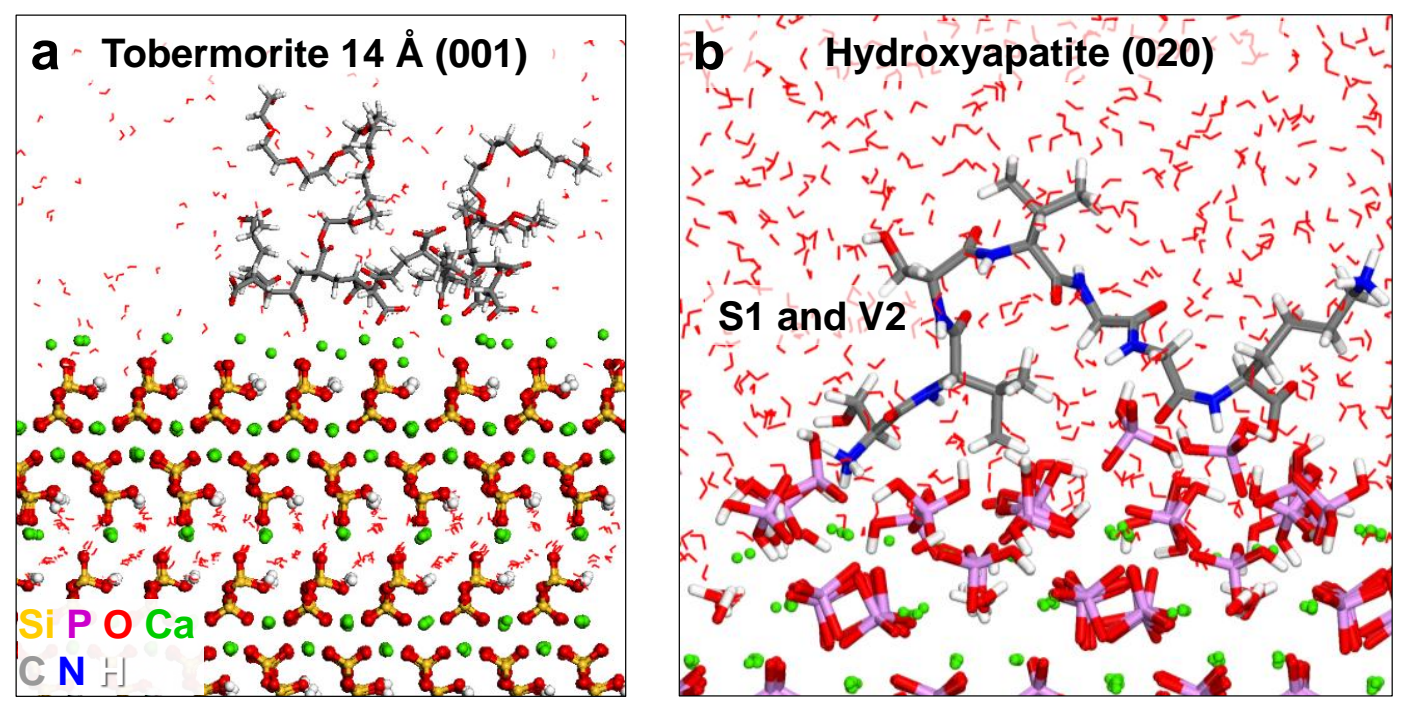

Figure 5. Examples of polymer and peptide adsorption on silicate and phosphate surfaces. (a) Tobermorite $14 \AA$ in contact with water and a polyacrylate ester (16-mer) with two polyethylene oxide side chains (6-mer) at $\mathrm{pH} \sim 12$, used as a superplasticizer in Portland cement. (b) Adsorption of peptide SVSVGGK on a hydroxyapatite (020) prismatic plane at $\mathrm{pH} \sim 5$. The peptide was identified by phage display and the S1 and V2 residues are predominantly bound to this facet.

\section{Conclusions and Perspectives}

The capabilities of current nonbonded potentials to predict structural properties of glasses and silicates have been explained, as well as the capabilities of chemically realistic bonded potentials to predict surface properties and specific binding of biomolecules. The computational 
exploration of specific binding of peptides and drugs to oxide surfaces, the simulation of composite materials such as polymer/glass systems, collagen/apatite composites, bone, cement materials, as well as mineralization mechanisms of common oxide nanostructures has become feasible. Recent developments of chemically realistic surface models that take into account experimental knowledge of surface chemistry and $\mathrm{pH}$ dependent acid-base equilibria remove a large barrier towards the predictive study of nucleation, growth, and dissolution at the nanometer scale. Opportunities include the development of accurate potentials for a broader range of important inorganic compounds as well as of reactive potentials for common chemical processes. The creation of a graphical user interface to envelope expanding surface model databases and force fields, as well as to automate the generation of simulation input for inorganic-organic systems can benefit a broader user community and ease modeling of many materials interfaces that remain unknown to date.

\section{Acknowledgements}

The author acknowledges support from the National Science Foundation (DMR-1437355, CBET-1530790), ONR-MURI (N00014-14-1-0675), ACS-PRF (54135-ND10), AFOSR (FA9550-14-1-0194), the University of Akron, the University of Colorado-Boulder, and the Ohio Supercomputing Center.

\section{References}

1. S. Brunauer, P. H. Emmett and E. Teller, J. Am. Chem. Soc., 1938, 60, 309-319.

2. $\quad$ S. Brunauer, D. L. Kantro and C. H. Weise, Can. J. Chem., 1956, 34, 1483-1496.

3. Silica: Physical Behavior, Geochemistry, and Materials Applications, Heaney, P. J., Prewitt, C. T., Gibbs, G. V., eds., In: Reviews in Mineralogy, Vol. 29; Mineralogical Society of America, New Jersey, USA, 1994.

4. R. K. Iler, The Chemistry of Silica: Solubility, Polymerization, Colloid and Surface 
Properties, and Biochemistry, John Wiley \& Sons, New York, 1979.

5. A. P. Legrand, The Surface Properties of Silica, John Wiley \& Sons, New York, 1998, p. 72.

6. W. E. G. Muller, H. C. Schroder, Z. Burghard, D. Pisignano and X. H. Wang, Chem. Eur. J., 2013, 19, 5790-5804.

7. R. R. Naik, L. L. Brott, S. J. Clarson and M. O. Stone, J. Nanosci. Nanotechnol., 2002, 2, 95-100.

8. P. A. Patel, J. Eckart, M. C. Advincula, A. J. Goldberg and P. T. Mather, Polymer, 2009, 50, 1214-1222.

9.* S. V. Patwardhan, F. S. Emami, R. J. Berry, S. E. Jones, R. R. Naik, O. Deschaume, H. Heinz and C. C. Perry, J. Am. Chem. Soc., 2012, 134, 6244-6256.

10. P. Podsiadlo, A. K. Kaushik, E. M. Arruda, A. M. Waas, B. S. Shim, J. Xu, H. Nandivada, B. G. Pumplin, J. Lahann, A. Ramamoorthy and N. A. Kotov, Science, 2007, 318, 80-83.

11. A. Rimola, D. Costa, M. Sodupe, J.-F. Lambert and P. Ugliengo, Chem. Rev., 2013, 113, 4216-4313.

12. A. Stein, B. J. Melde and R. C. Schroden, Adv. Mater., 2000, 12, 1403-1419.

13. M. Sumper and E. Brunner, Adv. Funct. Mater., 2006, 16, 17-26.

14. D. Y. Zhao, J. L. Feng, Q. S. Huo, N. Melosh, G. H. Fredrickson, B. F. Chmelka and G. D. Stucky, Science, 1998, 279, 548-552.

15. F. Geng, R. Ma, A. Nakamura, K. Akatsuka, Y. Ebina, Y. Yamauchi, N. Miyamoto, Y. Tateyama and T. Sasaki, Nature Comm., 2013, 4, 1632.

16. M. Liu, Y. Ishida, Y. Ebina, T. Sasaki, T. Hikima, M. Takata and T. Aida, Nature, 2015, 517, 68-72.

17. L. M. Gordon and D. Joester, Nature, 2011, 469, 194-197.

18. S. V. Dorozhkin, Am. J. Biomed. Eng., 2012, 2, 48-97.

19. P. J. M. Smeets, K. R. Cho, R. G. E. Kempen, N. Sommerdijk and J. J. De Yoreo, Nat. Mater., 2015, 14, 394-399.

20. K. L. Scrivener and A. Nonat, Cem. Concr. Res., 2011, 41, 651-665.

21.* G. H. Bolt, J. Phys. Chem., 1957, 61, 1166-1169.

22. J. A. G. Taylor and J. A. Hockey, J. Phys. Chem., 1966, 70, 2169-2172.

23. W. Stober, A. Fink and E. Bohn, J. Colloid Interface Sci., 1968, 26, 62-69.

24. T. F. Tadros and J. Lyklema, J. Electroanal. Chem. Interfacial Electrochem., 1968, 17, 267-275.

25. R. P. Abendroth, J. Colloid Interface Sci., 1970, 34, 591-596.

26. F. S. Baker and K. S. W. Sing, J. Colloid Interface Sci., 1976, 55, 605-613.

27. D. E. Yates and T. W. Healy, J. Colloid Interface Sci., 1976, 55, 9-19.

28. S. Kondo, H. Fujiwara, T. Ichii and I. Tsuboi, J. Chem. Soc., Faraday Trans. I, 1979, 75, 646-651.

29. S. K. Milonjić, Colloids Surf., 1987, 23, 301-312.

30. R. Zerrouk, A. Foissy, R. Mercier, Y. Chevallier and J.-C. Morawski, J. Colloid Interface Sci., 1990, 139, 20-29.

31. W. A. House and D. R. Orr, J. Chem. Soc., Faraday Trans., 1992, 88, 233-241.

32. M. Handke and W. Mozgawa, Vib. Spectrosc., 1993, 5, 75-84.

33. L. T. Zhuravlev, Colloids Surf., A, 1993, 74, 71-90.

34. J. M. Douillard, M. Elwafir and S. Partyka, J. Colloid Interface Sci., 1994, 164, 238-244.

35. K. J. Kingma and R. J. Hemley, Am. Mineral., 1994, 79, 269-273. 
36. G. Vigil, Z. H. Xu, S. Steinberg and J. Israelachvili, J. Colloid Interface Sci., 1994, 165, 367-385.

37. C. Dorémieux-Morin, L. Heeribout, C. Dumousseaux, J. Fraissard, H. Hommel and A. P. Legrand, J. Am. Ceram. Soc., 1996, 118, 13040-13045.

38. J. Sonnefeld, J. Colloid Interface Sci., 1996, 183, 597-599.

39. N. Kröger, R. Deutzmann and M. Sumper, Science, 1999, 286, 1129-1132.

40. J. N. Cha, G. D. Stucky, D. E. Morse and T. J. Deming, Nature, 2000, 403, 289-292.

41. W. Ogasawara, W. Shenton, S. A. Davis and S. Mann, Chem. Mater, 2000, 12, 2835-2837.

42. L. L. Brott, R. R. Naik, D. J. Pikas, S. M. Kirkpatrick, D. W. Tomlin, P. W. Whitlock, S. J. Clarson and M. O. Stone, Nature, 2001, 413, 291-293.

43. N. Kröger, S. Lorenz, E. Brunner and M. Sumper, Science, 2002, 298, 584-586.

44. E. Ruiz-Hitzky, Chem. Record, 2003, 3, 88-100.

45. S. V. Patwardhan, S. J. Clarson and C. C. Perry, Chem. Commun., 2005, 1113-1121.

46. S. V. Patwardhan, G. Patwardhan and C. C. Perry, J. Mater. Chem., 2007, 17, 2875-2884.

47. V. Puddu and C. C. Perry, ACS Nano, 2012, 6, 6356-6363.

48.* V. Puddu and C. C. Perry, Langmuir, 2014, 30, 227-233.

49.* F. S. Emami, V. Puddu, R. J. Berry, V. Varshney, S. V. Patwardhan, C. C. Perry and H. Heinz, Chem. Mater., 2014, 26, 2647-2658.

50. M. J. Sanders, M. Leslie and C. R. A. Catlow, J. Chem. Soc.-Chem. Commun., 1984, 1271-1273.

51. T. P. M. Goumans, A. Wander, W. A. Brown and C. R. A. Catlow, Phys. Chem. Chem. Phys., 2007, 9, 2146-2152.

52. $\quad$ S. H. Garofalini, J. Chem. Phys., 1982, 76, 3189-3192.

53. B. P. Feuston and S. H. Garofalini, J. Chem. Phys., 1988, 89, 5818-5824.

54.* $\quad$ B. W. H. van Beest and G. J. Kramer, Phys. Rev. Lett., 1990, 64, 1955-1958.

55. J. R. Hill and J. Sauer, J. Phys. Chem., 1994, 98, 1238-1244.

56. J. R. Hill and J. Sauer, J. Phys. Chem., 1995, 99, 9536-9550.

57. K. D. Lobel, J. K. West and L. L. Hench, J. Mater. Sci. Lett., 1996, 15, 648-650.

58. D. A. Sverjensky and N. Sahai, Geochim. Cosmochim. Acta, 1996, 60, 3773-3797.

59. K. Vollmayr, W. Kob and K. Binder, Phys. Rev. B, 1996, 54, 15808-15827.

60. J. Horbach and W. Kob, Phys. Rev. B, 1999, 60, 3169-3181.

61. J. Horbach, W. Kob and K. Binder, Phys. Rev. Lett., 2002, 88, 125502.

62.* H. Heinz and U. W. Suter, J. Phys. Chem. B, 2004, 108, 18341-18352.

63. J. Du and A. N. Cormack, J. Am. Ceram. Soc., 2005, 88, 2532-2539.

64. H. Heinz, H. Koerner, K. L. Anderson, R. A. Vaia and B. L. Farmer, Chem. Mater, 2005, 17, 5658-5669.

65. J. J. Yang, S. Meng, L. F. Xu and E. G. Wang, Phys. Rev. B, 2005, 71.

66. E. R. Cruz-Chu, A. Aksimentiev and K. Schulten, J. Phys. Chem. B, 2006, 110, 21497-21508.

67. H. Heinz, R. A. Vaia and B. L. Farmer, J. Chem. Phys., 2006, 124, 224713.

68. P. E. M. Lopes, V. Murashov, M. Tazi, E. Demchuk and A. D. MacKerell, J. Phys. Chem. $B, 2006,110,2782-2792$.

69. A. A. Hassanali and S. J. Singer, J. Phys. Chem. B, 2007, 111, 11181-11193.

70. A. G. Kalinichev, J. W. Wang and R. J. Kirkpatrick, Cem. Concr. Res., 2007, 37, 337-347.

71. A. Pedone, G. Malavasi, M. C. Menziani, U. Segre, F. Musso, M. Corno, B. Civalleri and 
P. Ugliengo, Chem. Mater., 2008, 20, 2522-2531.

72. J. P. Allen, W. Gren, M. Molinari, C. Arrouvel, F. Maglia and S. C. Parker, Molecular Simulation, 2009, 35, 584-608.

73. A. A. Hassanali, H. Zhang, C. Knight, Y. K. Shin and S. J. Singer, J. Chem. Theory Comput., 2010, 6, 3456-3471.

74. R. Shahsavari, R. J. M. Pellenq and F. J. Ulm, Phys. Chem. Chem. Phys., 2011, 13, 1002-1011.

75. A. Butenuth, G. Moras, J. Schneider, M. Koleini, S. Köppen, R. Meißner, L. B. Wright, T. R. Walsh and L. C. Ciacchi, Phys. Status Solidi B, 2012, 249, 292-305.

76. J. Schneider and L. C. Ciacchi, J. Am. Chem. Soc., 2012, 134, 2407-2413.

77. R. K. Mishra, R. J. Flatt and H. Heinz, J. Phys. Chem. C, 2013, 117, 10417-10432.

78.* F. S. Emami, V. Puddu, R. J. Berry, V. Varshney, S. V. Patwardhan, C. C. Perry and H. Heinz, Chem. Mater., 2014, 26, 5725-5734.

79.* A. Pedone, J. Phys. Chem. C, 2009, 113, 20773-20784.

80.* H. Heinz, T.-J. Lin, R. K. Mishra and F. S. Emami, Langmuir, 2013, 29, 1754-1765.

81. R. T. Cygan, J. A. Greathouse, H. Heinz and A. G. Kalinichev, J. Mater. Chem., 2009, 19, 2470-2481.

82. E. Flikkema and S. T. Bromley, Chem. Phys. Lett., 2003, 378, 622-629.

83. P. Ugliengo, M. Sodupe, F. Musso, I. J. Bush, R. Orlando and R. Dovesi, Adv. Mater., 2008, 20, 4579-4583.

84. K. Chenoweth, A. C. T. van Duin and W. A. Goddard, J. Phys. Chem. A, 2008, 112, 1040-1053.

85. R. N. Costa Filho, G. Alencar, B. S. Skagerstam and J. S. Andrade, Epl, 2013, 101, 10009.

86.* A. Meyer, J. Horbach, W. Kob, F. Kargl and H. Schober, Phys. Rev. Lett., 2004, 93, 027801.

87. D. I. Grimley, A. C. Wright and R. N. Sinclair, J. Non-Cryst. Solids, 1990, 119, 49-64.

88. CRC Handbook of Chemistry and Physics 89th edn., CRC Press, Boca Raton, FL, 2008.

89. D. J. Cooke and J. A. Elliott, J. Chem. Phys., 2007, 127, 104706.

90. C. L. Freeman, J. H. Harding and D. M. Duffy, Langmuir, 2008, 24, 9607-9615.

91. J. W. Shen, C. L. Li, N. F. A. van der Vegt and C. Peter, J. Phys. Chem. C, 2013, 117, 6904-6913.

92. T. Z. Lin, Force Field Parameters and Atomistic Surface Models for Hydroxyapatite and Analysis of Biomolecular Adsorption at Aqueous Interfaces, Retrieved from https://etd.ohiolink.edu, University of Akron, PhD thesis, 2013.

93. H. Heinz, J. Phys.: Condens. Matter, 2014, 26, 244105.

94. P. W. Brown and R. I. Martin, J. Phys. Chem. B, 1999, 103, 1671-1675.

95. H. Tanaka, M. Chikazawa, K. Kandori and T. Ishikawa, Phys. Chem. Chem. Phys., 2000, 2, 2647-2650.

96. R. Astala and M. J. Stott, Phys. Rev. B, 2008, 78, 075427.

97. R. Bhowmik, K. S. Katti and D. Katti, Polymer, 2007, 48, 664-674.

98. M. Corno, A. Rimola, V. Bolis and P. Ugliengo, Phys. Chem. Chem. Phys., 2010, 12, 6309-6329.

99. N. H. de Leeuw, J. Mater. Chem., 2010, 20, 5376-5389.

100. N. L. Huq, K. J. Cross and E. C. Reynolds, J. Mol. Model., 2000, 6, 35-47.

101. S. Peroos, Z. Du and N. H. de Leeuw, Biomaterials, 2006, 27, 2150-2161. 
102. J. Robinson, I. Cukrowski and H. M. Marques, J. Mol. Struct. Theochem, 2006, 825, 134-142.

103.* M. L. Machesky, M. Predota, D. J. Wesolowski, L. Vlcek, P. T. Cummings, J. Rosenqvist, M. K. Ridley, J. D. Kubicki, A. V. Bandura, N. Kumar and J. O. Sofo, Langmuir, 2008, 24, 12331-12339.

104. J. Feng, J. M. Slocik, M. Sarikaya, R. R. Naik, B. L. Farmer and H. Heinz, Small, 2012, 8, 1049-1059.

105. K. C. Jha, H. Liu, M. R. Bockstaller and H. Heinz, J. Phys. Chem. C, 2013, 117, 25969-25981.

106. N. M. Bedford, H. Ramezani-Dakhel, J. M. Slocik, B. D. Briggs, Y. Ren, A. I. Frenkel, V. Petkov, H. Heinz, R. R. Naik and M. R. Knecht, ACS Nano, 2015, 9, 5082-5092.

107. H. Ramezani-Dakhel, P. A. Mirau, R. R. Naik, M. R. Knecht and H. Heinz, Phys. Chem. Chem. Phys., 2013, 15, 5488-5492.

108. H. Ramezani-Dakhel, L. Y. Ruan, Y. Huang and H. Heinz, Adv. Funct. Mater. , 2015, 25, 1374-1384.

109. L. Ruan, H. Ramezani-Dakhel, C.-Y. Chiu, E. Zhu, Y. Li, H. Heinz and Y. Huang, Nano Lett., 2013, 13, 840-846.

110. L. Y. Ruan, H. Ramezani-Dakhel, C. Lee, Y. J. Li, X. F. Duan, H. Heinz and Y. Huang, ACS Nano, 2014, 8, 6934-6944.

111. Z. H. Tang, J. P. Palafox-Hernandez, W. C. Law, Z. E. Hughes, M. T. Swihart, P. N. Prasad, M. R. Knecht and T. R. Walsh, ACS Nano, 2013, 7, 9632-9646. 


\section{Graphical Abstract}

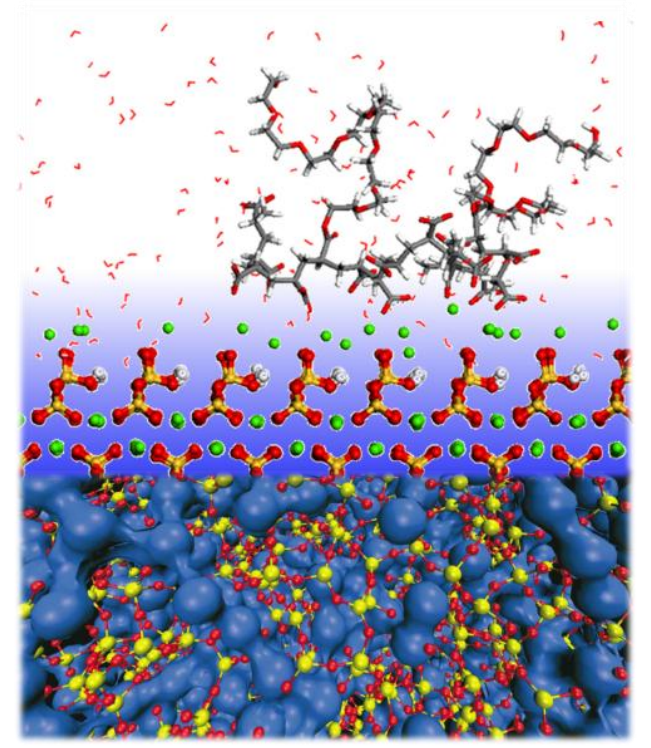

28

29

30

31

32

33

34

35

36 